\title{
Collapsing Mechanisms of the Typical Cohesive Riverbank along the Ningxia-Inner Mongolia Catchment
}

\author{
Guosheng Duan ${ }^{1}$, Anping Shu ${ }^{1, *}$, Matteo Rubinato ${ }^{2}{ }^{\mathbb{D}}$, Shu Wang ${ }^{1}$ and Fuyang Zhu ${ }^{1}$ \\ 1 School of Environment, Key Laboratory of Water and Sediment Sciences of MOE, Beijing Normal University, \\ Beijing 100875, China; duanguosheng2004@163.com (G.D.); wangshu861217@gmail.com (S.W.); \\ fuyangzhu1017@gmail.com (F.Z.) \\ 2 Department of Civil and Structural Engineering, The University of Sheffield, Sir Frederick Mappin Building, \\ Mappin Street, Sheffield S1 3JD, UK; m.rubinato@sheffield.ac.uk \\ * Correspondence: shuap@bnu.edu.cn; Tel.: +86-10-5880-2928
}

Received: 7 August 2018; Accepted: 11 September 2018; Published: 18 September 2018

\begin{abstract}
As one of the major sediment sources in rivers, bank collapse often occurs in the Ningxia-Inner Mongolia catchment and, to date, it caused substantial social, economic and environmental problems in both local areas and downstream locations. To provide a better understanding of this phenomenon, this study consisted of modifying the existing Bank Stability and Toe Erosion Model (BSTEM), commonly used to investigate similar phenomena, introducing new assumptions and demonstrating its applicability by comparing numerical results obtained against field data recorded at six gauging stations (Qingtongxia, Shizuishan, Bayan Gol, Sanhuhekou, Zhaojunfen, and Toudaoguai). Furthermore, the impact of multiple factors typical of flood and dry seasons on the collapse rate was investigated, and insights obtained should be taken into consideration when completing future projects of river adaptation and river restoration.
\end{abstract}

Keywords: Ningxia-Inner Mongolia; Yellow River; riverbank collapse; BSTEM model; flood \& dry season; sediment transport

\section{Introduction}

Riverbank collapse is a phenomenon caused by several natural factors (e.g., intense rainfall, site topography, properties of the river bed and hydraulic conditions of the river flow) [1] and artificial factors (e.g., man-made bank undercutting, basal clean-out) [2]. The Yellow River is the China's second-longest river and previous studies [3] confirmed that $518.38 \mathrm{~km}^{2}$ of the riverbank along the Ningxia-Inner Mongolia part of the Yellow River was eroded between 1958 and 2008. This elevated rate of riverbank erosion is due to continuous variations of flow levels, causing the deposition of loose riverbed material in alluvial plains, especially after heavier rainfall events typical of climate change [4,5]. To date, riverbank erosion has caused substantial social (e.g., traffic disruption due to flooding), economic (e.g., loss of farm land) and environmental problems (e.g., sediment dynamics and water quality) in both local areas and downstream locations [6,7].

Previous studies were completed to tackle this challenge and to identify what can induce riverbanks to collapse in catchments in both developing and developed countries. Grabowski [8] found that the soil texture, the soil structure, the unit weight and water composition $[9,10]$ all play a principal role on the banks erosion. While non-cohesive banks are eroded through discrete particle entrainment that can be quantified using the magnitude of the shear stress and the particle size [11,12], cohesive banks are eroded through entrainment of aggregates [13] and this mechanism is very challenging to diagnose when considering the electrochemical forces acting between them $[14,15]$. The detachment 
and erosion phenomena of cohesive material by gravity and/or flowing water are typically controlled by a variety of physical, electrical and chemical forces, such as cohesion, electrochemical forces, pore-water pressure and matric suction [15]. These forces within and between aggregates cause their erosion to be complex. Furthermore, cohesive riverbanks are usually poorly drained due to their silt and clay composition, and thus may experience excess pore water pressures, one of the main agents of subaerial erosion. Clayey banks are also susceptible to desiccation cracking and slaking from wetting-drying cycles [16]. Numerous studies have examined the impact of water content on the riverbank erosion [17-22] while other studies have investigated the subaerial erosion due to the weakening and weathering of bank materials [23-25]. Additionally, Yu [26] completed a series of experimental tests to quantify the influence and the impact of the water infiltration on bank collapse and consequent sediment deposition. They identified that partial erosion can be due to fluvial hydraulic forces or gravitational forces. Moreover, total erosion of the bank can be generated if both forces are combined at their maximum magnitude, with a consequent disintegration of the bank and the transportation of fallen blocks within the flow, changing the bed elevation. Focusing on the Ningxia-Inner Mongolia banks, the erosion process has been found to be influenced by three specific factors: (i) the sand blown by the wind from the desert [27-30]; (ii) the sediment transported by the river from the upstream catchment [31,32]; and (iii) the material falling from the bank due to natural collapse [33]. It is fundamental to replicate all these governing processes within numerical models when assessing stability of the riverbanks. A large amount of literature is available and it covers all the numerical modeling aspects investigated to date [34-38]. One of the numerical tools most commonly used is the Bank Stability and Toe Erosion Model (BSTEM), developed by the National Sedimentation Laboratory in Oxford, Mississippi, USA [39], which has been continually modified and improved by the authors since its creation to improve its performance. To model the riverbanks' stability, BSTEM calculates a factor of safety $\left(F_{s}\right)$ for multi-layers combining three equilibrium-method models: (i) the layers simulated are horizontal; (ii) vertical slices simulate tension crack; and (iii) the common failure mechanisms are cantilever failures. BSTEM also assumes that all the collapsed material is totally removed from the bank and does not accumulate on the toe [40]. BSTEM is frequently used to simulate: (i) the banks' stability and the consequent sediment loading inside the river [41]; (ii) stream rehabilitation projects [42]; and (iii) erosion and failure mechanisms [43,44]. Despite several findings that have resulted in a better understanding of this phenomenon, to the authors' knowledge there is a lack of studies which involve the evaluation of BSTEM for long-term streambank erosion and consequent long-term failure.

Therefore, to fill this gap, this work comprises a collection of field datasets in the Ningxia-Inner Mongolia area that were implemented on the BSTEM model to obtain a new solution to the mechanisms of long-term bank erosion. To achieve that, three hypothesis different from those applied on the original BSTEM model were executed: (i) when the soil collapses from the bank, part of it is washed away by the water, and the remaining part accumulates on the toe; (ii) the shape of the material that accumulates on the toe is considered to have a triangle form considering the cross-sectional view and the angle away from the river bank is the angle of repose of the sediment, which is taken as 30 degrees; and (iii) the downstream area of a bank is considered the first one to be affected by the collapse process.

The paper is organized as follows. In the next sections the study area, the procedure to collect field data and the numerical analysis applied to replicate the river bank collapse recorded (Section 2) are described. Section 3 presents the comparison between numerical and experimental datasets and the factors that could influence the rate of collapse are discussed. Finally, Section 4 reports the conclusions.

\section{Materials and Methods}

\subsection{Case Study}

The Ningxia-Inner Mongolia catchment (Figure 1) is located in the lower part of the upper Yellow River and has a length of $913.5 \mathrm{~km}$, starting from Qingtongxia (Ningxia Hui autonomous 
region) and ending at Hekouzhen (Inner Mongolia autonomous region). This site includes six gauging stations (Qingtongxia, Shizuishan, Bayan Gol, Sanhuhekou, Zhaojunfen, and Toudaoguai) and it is characterized by four desert regions (HedongSandyland, Ulan Buh Desert, Tengger Desert and Hobq Desert) and two alluvial plains (Yinchuan Plain and Hetao Plain).

The climate of this region can be classified as temperate continental climate, which is characterized by long cold winters, and warm to hot summers [45]. The annual rainfall (maximum and minimum peaks commonly reached in summer and winter, respectively) ranges from 100 to $288 \mathrm{~mm}$.

The case study selected is located in Dengkou which is in the Inner Mongolia Province. The gauging station Bayan Gol is adjacent to it. Being part of the Hetao plain, the Dengkou catchment is characterized by a low gradient $(\approx 0.17 \%$ o $)$ and loose riverbed materials. This site was carefully chosen based on three specific criteria. Firstly, preliminary monitoring datasets of this site have confirmed that the riverbank was actively retreating. Secondly, the site was sufficiently close to a gauging station (about $5 \mathrm{~km}$ ), hence detailed rainfall readings including time-series, frequencies and water surface elevations associated with each flow condition flowing next to the bank site were available and could be collected. Last but not least, the morphology and the soil properties of this area are representative of the cohesive streambank along all the Ningxia-Inner Mongolia catchment which has been drastically eroded from 1958 to 2008 [3]. Therefore, it is fundamental to provide a better understanding of this phenomenon, especially in this zone, to provide mitigation measures and plan actions to reduce the effects due to erosion of the riverbanks.

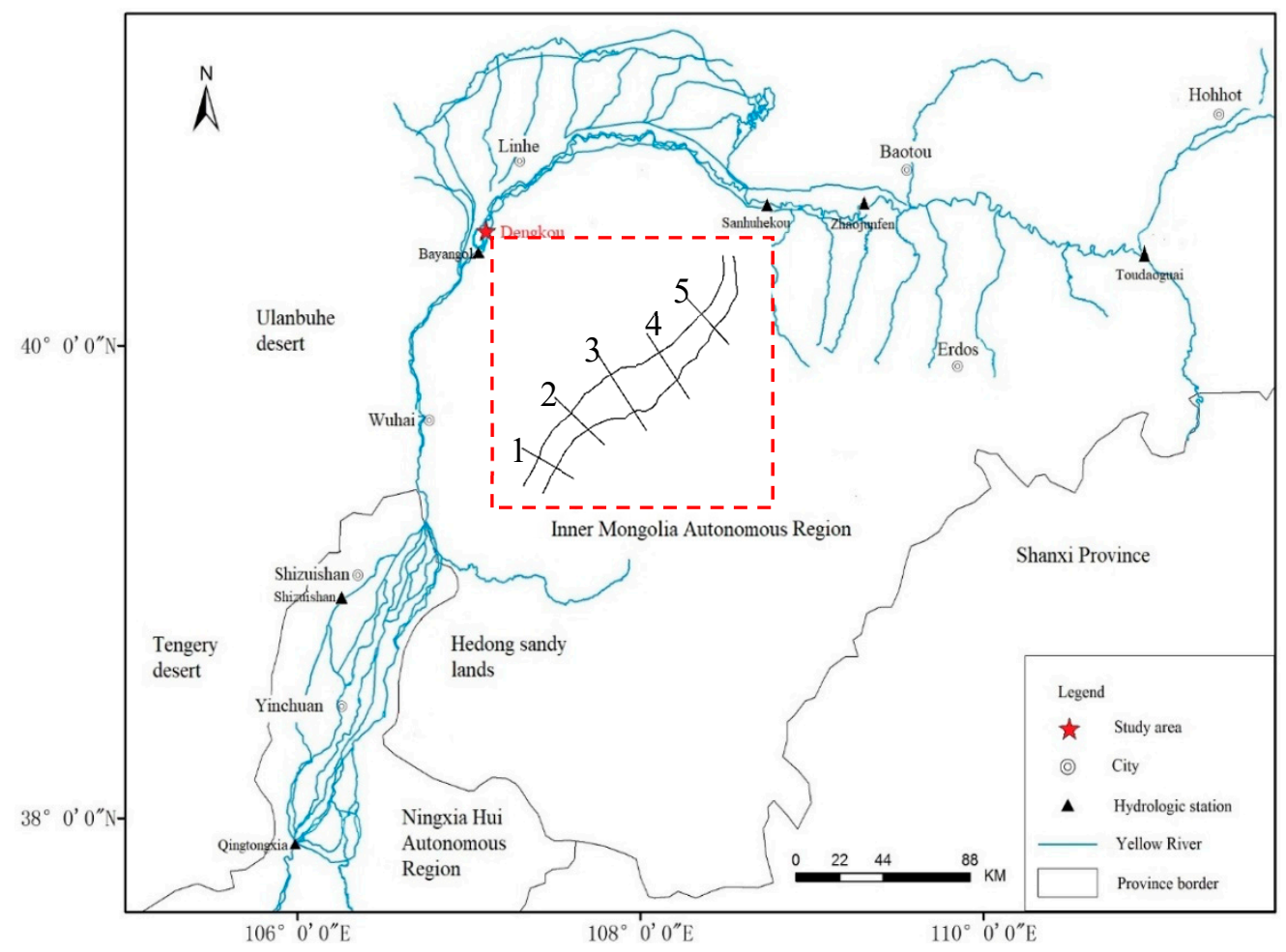

Figure 1. Location of the case study considered for this work. 1, 2, 3, 4 and 5 are the five surveying cross sections (500 $\mathrm{m}$ far from each other) selected for the collection of field-data.

\subsection{Field Data}

To analyze the complex processes of riverbank collapse affecting Dengkou, it was necessary to inspect the nature of the bank and the typical flow conditions in the parts of the Yellow river crossing this area. Five cross sections (1, 2, 3, 4 and 5, Figure 1), spaced $500 \mathrm{~m}$ from each other, were identified along the banks for the acquisition of field datasets. Parameters and methods selected by the authors for the monitoring and collection of datasets from the field study are displayed in Table 1. 
Table 1. Indexes and methods for in-site measurement.

\begin{tabular}{cccc}
\hline & Bank Shape & Soil Composition & Mechanical Properties \\
\hline \multirow{3}{*}{ Parameter monitored } & Bank height $(\mathrm{m})$ & Median diameter $(\mu \mathrm{m})$ & Critical shear stress $(\mathrm{kPa})$ \\
& Bank gradient $\left(^{\circ}\right)$ & Unit weight $\left(\mathrm{g} / \mathrm{cm}^{3}\right)$ \\
Length of bank toe $(\mathrm{m})$ & Moisture content $(\%)$ & Internal friction angle $\left(^{\circ}\right)$ \\
\hline $\begin{array}{c}\text { Equipment utilized for } \\
\text { the monitoring }\end{array}$ & $\begin{array}{c}\text { Gradometer }\left( \pm 1^{\circ}\right), \\
\text { Tape }( \pm 1 \mathrm{~cm})\end{array}$ & $\begin{array}{c}\text { Scale, Laser particle sizer } \\
( \pm 5 \mu \mathrm{m})\end{array}$ & Direct shear apparatus \\
\hline
\end{tabular}

Additionally, to measure the magnitude of bank collapse along the area of study, five stakes were positioned vertically to the flow direction at each section selected for the monitoring (Figure 2). Five measurements were conducted respectively on 21 May, 13 July, 9 August, 23 September and 30 September in 2011 to quantify the collapse distance. The collapse distances between each section recorded are displayed in Table 2.

Table 2. Collapse distances (m) recorded in 2011.

\begin{tabular}{cccccc}
\hline Time Scale & Section 1 & Section 2 & Section 3 & Section 4 & Section 5 \\
\hline 21 May-13 July & 4.60 & 4.50 & 5.80 & 5.30 & 5.60 \\
13 July-9 August & 3.05 & 2.80 & 3.10 & 3.95 & 3.60 \\
9 August-23 September & 5.25 & 5.08 & 6.80 & 6.20 & 6.50 \\
23 September-30 September & 1.68 & 1.45 & 1.10 & 2.40 & 1.45 \\
Total & 14.58 & 13.81 & 16.80 & 17.85 & 17.15 \\
\hline
\end{tabular}

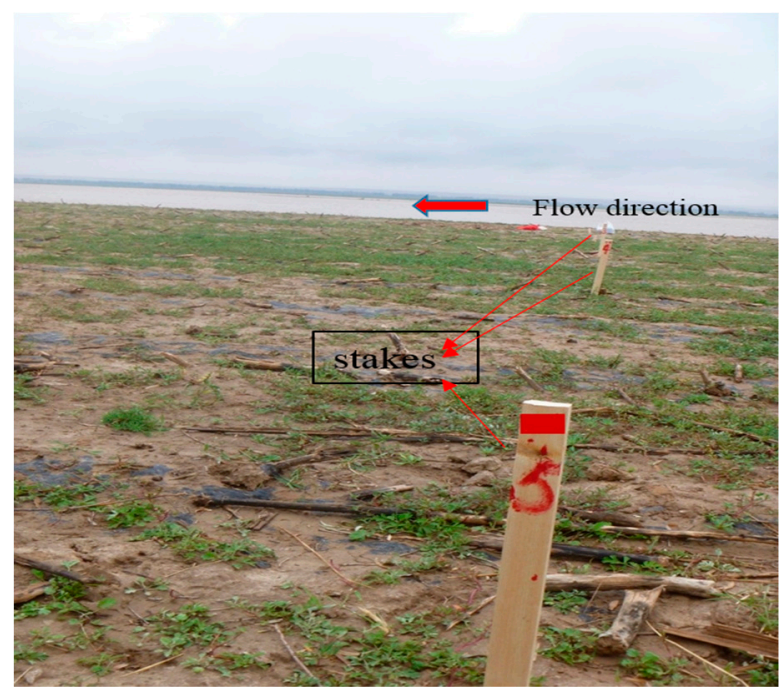

Figure 2. Collapse distance measurement for surveying Section 1.

\subsubsection{Hydrologic Data}

Monthly average hydrologic datasets (2011, year of site inspection) obtained from the gauging station Bayan Gol used for this study are showed in Table 3. 
Table 3. Monthly average hydrologic data (2011).

\begin{tabular}{cccccc}
\hline Month & Flow $\left(\mathbf{m}^{\mathbf{3}} \mathbf{s}\right)$ & $\begin{array}{c}\text { Velocity } \\
\mathbf{( m / s )}\end{array}$ & $\begin{array}{c}\text { Water } \\
\text { Depth }(\mathbf{m})\end{array}$ & $\begin{array}{c}\text { Sediment } \\
\text { Concentration } \mathbf{( k g / \mathbf { m } ^ { 3 } )}\end{array}$ & $\begin{array}{c}\text { Sediment Transport } \\
\text { Rate } \mathbf{( k g} / \mathbf{s})\end{array}$ \\
\hline 1 & 494.23 & 0.68 & 3.09 & 0.21 & 102 \\
2 & 568.11 & 0.74 & 3.02 & 0.22 & 123 \\
3 & 495.58 & 1.06 & 1.94 & 1.23 & 615 \\
4 & 684.77 & 1.08 & 1.34 & 2.16 & 1480 \\
5 & 444.00 & 0.89 & 1.03 & 0.64 & 283 \\
6 & 369.60 & 0.81 & 0.85 & 0.59 & 217 \\
7 & 368.35 & 0.87 & 0.83 & 0.77 & 1690 \\
8 & 528.00 & 1.32 & 0.94 & 3.20 & 1590 \\
9 & 817.30 & 1.42 & 1.40 & 1.95 & 779 \\
10 & 612.48 & 1.37 & 0.99 & 1.27 & 580 \\
11 & 495.90 & 1.18 & 0.62 & 1.17 & 1530 \\
12 & 592.52 & 0.95 & 2.00 & 2.58 & \\
\hline
\end{tabular}

\subsubsection{Bank Characteristics of Each Section}

Riverbank properties at each section (1, 2, 3, 4 and 5, Figure 1) were obtained through five field inspections in 2011 (1. 21 May, 2. 13 July, 3. 9 August, 4. 23 September and 5. 30 September), and details are showed in Table 4. During the characteristic long cold winters in this region, the Yellow River typically freezes, hence the summer season has been selected as sampling period to avoid the quantification of additional effects on river bed changes [46,47] which could have made the already complex comparison between experimental datasets and numerical results even more challenging.

Table 4. Characteristics of the sections selected for this study.

\begin{tabular}{cccccccc}
\hline Section & $\begin{array}{c}\text { Bank } \\
\text { Height } \\
(\mathbf{m})\end{array}$ & $\begin{array}{c}\text { Bank } \\
\text { Gradient } \\
\left({ }^{\circ}\right)\end{array}$ & $\begin{array}{c}\text { Toe } \\
\text { Length } \\
(\mathbf{m})\end{array}$ & $\begin{array}{c}\text { Median } \\
\text { Diameter } \\
(\boldsymbol{\mu m})\end{array}$ & $\begin{array}{c}\text { Wet Unit } \\
\text { Weight } \\
\left(\mathbf{g} / \mathbf{c m}^{\mathbf{3}}\right)\end{array}$ & $\begin{array}{c}\text { Critical } \\
\text { Shear Stress } \\
(\mathbf{k P a})\end{array}$ & $\begin{array}{c}\text { Internal } \\
\text { Friction } \\
\text { Angle }\left({ }^{\circ}\right)\end{array}$ \\
\hline 1 & 1.9 & 82 & 0.85 & 33 & 1.55 & 7.2 & 32 \\
2 & 2.1 & 77 & 0.9 & 35 & 1.48 & 7.5 & 31 \\
3 & 2.3 & 81 & 0.95 & 32 & 1.50 & 7.3 & 32 \\
4 & 1.7 & 84 & 0.8 & 37 & 1.46 & 7.5 & 30 \\
5 & 1.6 & 86 & 0.75 & 30 & 1.52 & 7.2 & 31 \\
\hline
\end{tabular}

\subsection{Riverbank Collapse Characterisation}

When collecting field data, observations were made to get more insights about the erosion that typically affects the riverbanks of the Ningxia-Inner Mongolia catchment. Figure 3 shows an example of the real case study under investigation prior and after the erosion. Observations confirmed that the bank material is cohesive, the riverbank slope is steep $\left(77-86^{\circ}\right)$, and the pattern of bank collapse is considered to be planar, in conformity with previous studies conducted [48,49]. Additionally, while monitoring the site, it was possible to identify different stages of the continuous collapse process characterized as follows: (i) the bank toe erosion initiates (Figure 4a); (ii) tension cracks develop (Figure 4b); (iii) shearing starts and parts of the bank breaks and detaches from the main body (Figure 4c); (iv) bank failure occurs (Figure 4d). When the soil collapses from the bank, part of it is washed away by the water and the remaining part accumulates at the bank toe. The new shape of the bank including the additional material eroded then becomes the initial form of the next bank collapse. 


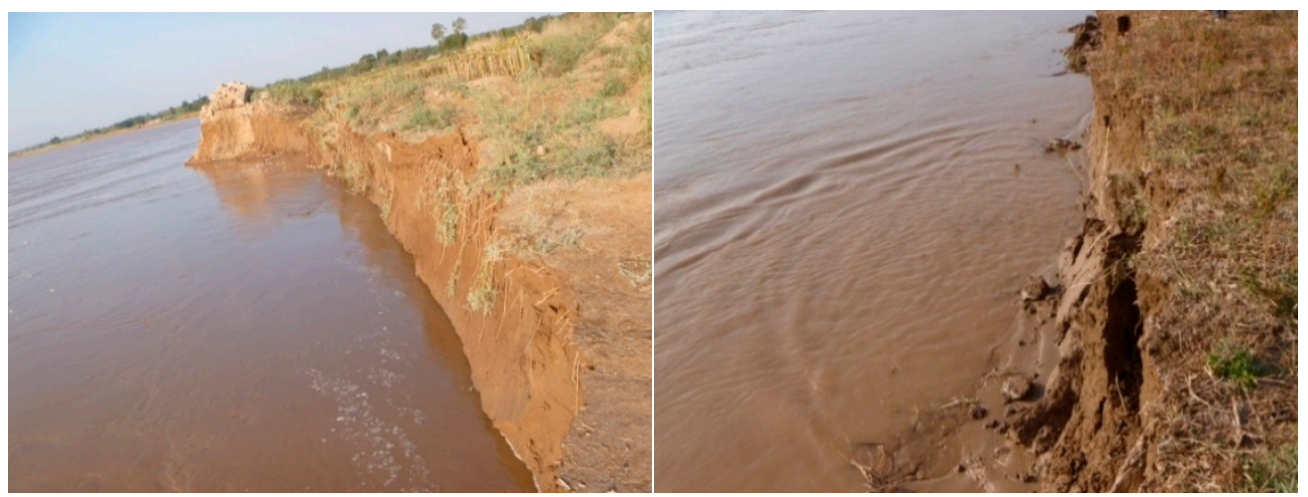

Figure 3. Example of the existing bank slope (left) and an example of riverbank collapse along Dengkou reach (right).
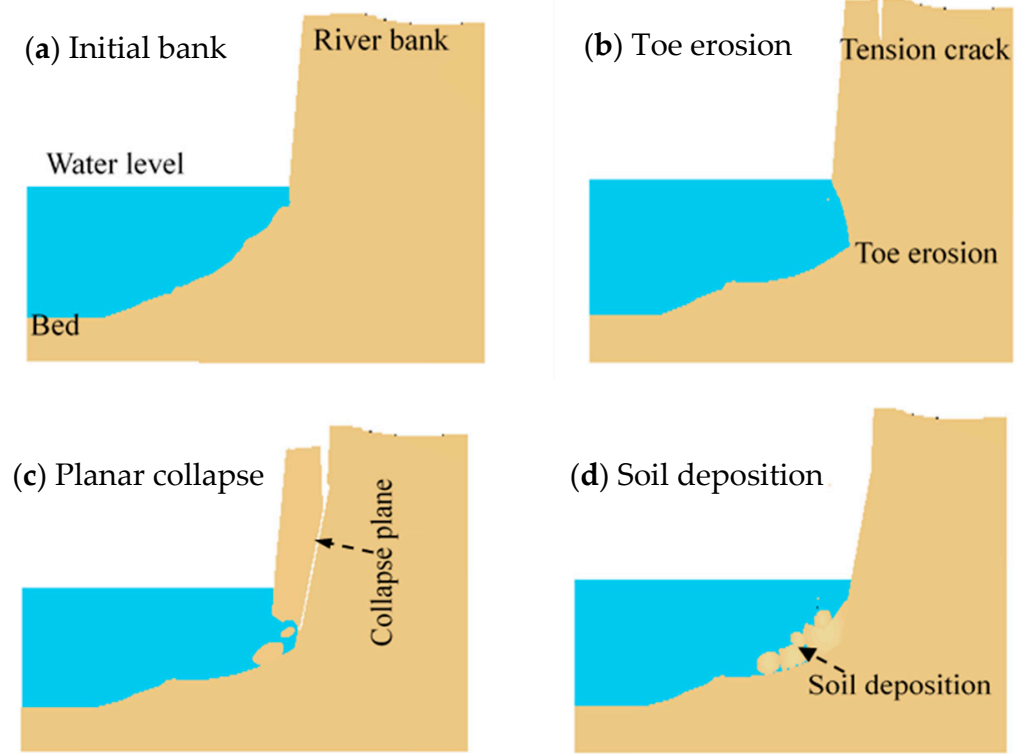

(d) Soil deposition

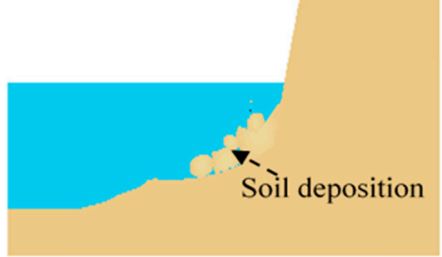

Figure 4. Typical riverbank processes observed at the case study of Ningxia-Inner Mongolia catchment.

\subsection{Numerical Modeling}

In this study, the BSTEM model, developed by the National Sedimentation Laboratory in Oxford, MS, USA, was used and modified according to the assumptions presented in the introduction.

\subsubsection{BSTEM Method}

There are two separate modules in the conventional BSTEM model: (i) the toe erosion module and (ii) the stability of the bank module [39]. Equation (1) is commonly applied to predict the width of the bank toe eroded due to the hydraulic conditions impacting on the cohesive riverbank [16,50-52]:

$$
B=\kappa\left(\tau-\tau_{c}\right)^{a} \Delta t
$$

where $B$ is the toe erosion width (m); $\kappa$ is the erodibility coefficient $\left(\mathrm{m}^{3} \mathrm{~N}^{-1} \mathrm{~s}^{-1}\right) ; \tau$ is the average shear stress $(\mathrm{Pa}) ; \tau_{c}$ is soil's critical shear stress $(\mathrm{Pa})$; $\mathrm{a}$ is an exponent usually assumed to be unity, $\Delta t$ is the time interval (s). $\kappa$ and $\tau_{c}$ are functions of the soil properties and they are characterized by the following relationship, $\kappa=0.2 \tau_{c}^{-0.5}$. For non-cohesive soils, $\tau_{c}$ is typically estimated based on the median particle diameter of the soil [53]. Rinaldi [54] noted the difficulty to accurately estimate $\kappa$ but despite that, other methods provided solutions via a variety of methods to calculate $\kappa$ and $\tau_{c}$. One of 
these methods was developed by Hanson [55] using an in situ jet-test device and his experimental results are currently used universally. In Equation (1), $\tau$ can be calculated using Equation (2):

$$
\tau=\gamma_{w} R S
$$

where $\gamma_{w}$ is the weight of water $\left(\mathrm{N} / \mathrm{m}^{3}\right) ; R$ is the hydraulic radius $(\mathrm{m}) ; S$ is the channel slope.

For the specific scenario of planar failure assumed for this study, the riverbank stability analysis involved the computation of a safety factor, identified as the ratio between the resisting and the driving forces applied to the failure zone, which is typically calculated by using Equation (3) [56-59]:

$$
F_{S}=\frac{S_{R}}{S_{D}}
$$

where $F_{S}$ is the safety factor with respect to bank failure $\left(F_{S}<1\right.$ indicates the possibility of an eventual collapse); $S_{R}$ is the shear strength of the soil $(\mathrm{kPa}) ; S_{D}$ is the driving stress $(\mathrm{Pa}) . S_{R}$ can be calculated using Equation (4):

$$
S_{R}=c^{\prime}+S \tan \phi^{b}+\Psi \tan \phi^{\prime}
$$

where $c^{\prime}$ is the effective cohesion (the effective cohesion of the soil is the cohesion of the soil in the anti-shear process) (Pa); $S$ is the normal stress $(\mathrm{Pa}) ; \phi^{b}$ is an angle that describes the relationship between the shear strength and the matric suction $\left(^{\circ}\right) ; \Psi$ is the matric suction which contrasts the pore-water pressure $(\mathrm{Pa}) ; \phi^{\prime}$ is the effective internal friction angle $\left({ }^{\circ}\right) . S_{D}$ can be calculated using Equation (5):

$$
S_{D}=W \sin \beta
$$

where $W$ is the weight of the wet soil per unit area of the failure plane $\left(\mathrm{Nm}^{-2}\right) ; \beta$ is the angle of the failure plane $\left(^{\circ}\right)$ [39]. Note that the BSTEM model takes $c^{\prime}$ into account to represent the cohesion effect. Nevertheless, the influence of cohesive materials on erosion would be considered through other approaches, as well. For example, Dodaro et al. $[60,61]$ modified Shields parameter to predict erosion phenomena at a cohesive sediment mixture.

\subsubsection{BSTEM Method Modified}

As defined in Section 2.3, the phenomenon of bank collapse is characterized by four different stages. Despite multiple factors influencing the rate of the riverbank collapse, as previously mentioned, continuous collapses are also affected by the intensity of the antecedent collapse magnitude. When the collapse happens, the riverbank affected typically divides into two sections within a moment-frame: one part collapsed is naturally washed away by the river and the remaining part usually deposits at the bank toe. Before the next bank collapse takes place, the additional deposited soil is eroded. Therefore, it is very important to characterize the continuous changing shape of the riverbank to correctly predict the effects of the continuous erosion. Although the original BSTEM model provides some insights into this process and is very helpful for the analysis of the riverbank stability, it should be noted that BSTEM assumes that the falling part which has collapsed from the riverbank does not accumulate on the toe and is immediately removed. Hence it does not accurately represent the reality of the entire erosion process typical on natural rivers. Authors observed multiple shapes and forms during the erosion process following the collapse of material and have tried to characterize each of them, but the literature published to date lacks formulae to accurately estimate and quantify the amount of material deposited. Therefore, to address this gap, three changes were made in the original BSTEM model as follows.

(i) The quantity of soil falling into the river and carried away by the natural streamflow in the form of suspended material can be calculated using Equation (6):

$$
M_{0}=\left(S_{*}-S_{v}\right) H d
$$


where $M_{0}$ is the weight of soil carried away per unit length $(\mathrm{kg} / \mathrm{m}) ; S_{v}$ is the sediment concentration $\left(\mathrm{kg} / \mathrm{m}^{3}\right)$, typically obtained by field monitoring; $H$ is the height of the bank $(\mathrm{m}) ; d$ is the width of the flow in the proximity of the bank $(\mathrm{m})$. Because there was a main current which was about $20 \mathrm{~m}$ away from the bank, $d$ is assumed as a constant $(d=20) . S_{*}$ is the capacity of the flow to transport suspended material $\left(\mathrm{kg} / \mathrm{m}^{3}\right)$ and can be calculated using Equation (7) [62]:

$$
S_{*}=K\left(U_{L}^{3} / g h \omega\right)^{m}
$$

where $K$ and $m$ are parameters that can be obtained from the literature [60]; $U_{L}$ is flow velocity $(\mathrm{m} / \mathrm{s})$; $g$ is gravitational acceleration $\left(\mathrm{m} / \mathrm{s}^{2}\right) ; h$ is water depth $(\mathrm{m})$; and $\omega$ is the velocity of the particles setting $(\mathrm{m} / \mathrm{s})$ which can be calculated by using Equation (8) [62]:

$$
\omega=\left(\gamma_{s}-\gamma_{w}\right) g D^{2} / 25.6 \gamma_{w} v
$$

where $D$ is the grain size of the material $(\mathrm{m}) ; v$ is kinematic viscosity coefficient $\left(\mathrm{m}^{2} / \mathrm{s}\right)$.

(ii) The quantity of deposition soil can be calculated by using Equation (9):

$$
M_{d}=\left(W_{0}-M_{0}\right) x
$$

where $M_{d}$ is the quantity of material deposited $(\mathrm{kg}) ; W_{0}$ is the quantity of material collapsed (excluding the part suspended in the flow) $(\mathrm{kg}) ; x$ is a ratio between the material deposited and the material collapsed.

(iii) The new shape generated by the deposition of material on the bank toe is assumed to be triangular and the angle away from the riverbank is the angle of repose of sediment. In general, loose sediment grains in water accumulate with an angle close to the sediment angle of repose $[63,64]$.

In the calculation process, the time step is selected as the hour. This decision is justified by the fact that since the flow rate, water depth, flow rate and other data are used as a daily average, the $24 \mathrm{~h}$ cycle was considered more appropriate. After the original boundary has passed $24 \mathrm{~h}$, the river bank stability was tested: if the river bank was still stable, then the next set of water depth and flow rate conditions was inserted and the river bank toe erosion module continued to run. When the river bank stability coefficient was less than 1 , the collapse occurred and consequently the collapse rate should have been recorded. For this scenario, the amount of collapse was calculated according to the shape of the collapse area identified, and the amount of sediment deposited at the foot of the slope was calculated by using Equations (6)-(9). The shape of the material deposited on the slope was considered to be triangular, and the angle away from the river bank was the angle of repose of the sediment, which was taken as 30 degrees. Based on the collapse rate, the new shape of the river bank was obtained and taken as a new initial condition for the next collapse.

The scheme utilized by the modified BSTEM model can be summarized with the flow chart displayed in Figure 5.

It is complex to quantify in real time the collapse processes along the entire riverbank of the study area due to flow conditions under continuous change, but it is possible to provide an approximation of the riverbank collapse processes by using averaged parameters such as monthly average water depths, flowrates, sediment concentration and average grain size. In addition, there are also parameters that require an accurate calibration during the entire calculation process, such as $x . \tau_{c}$ can be obtained by using values furnished in the literature [65]. By applying trial and error techniques, $x=0.39$ corresponds to the optimal numerical value to replicate the realistic distance of collapse measured for this case study and discrepancies obtained between numerical and field measurements are listed in Tables 5-9. 


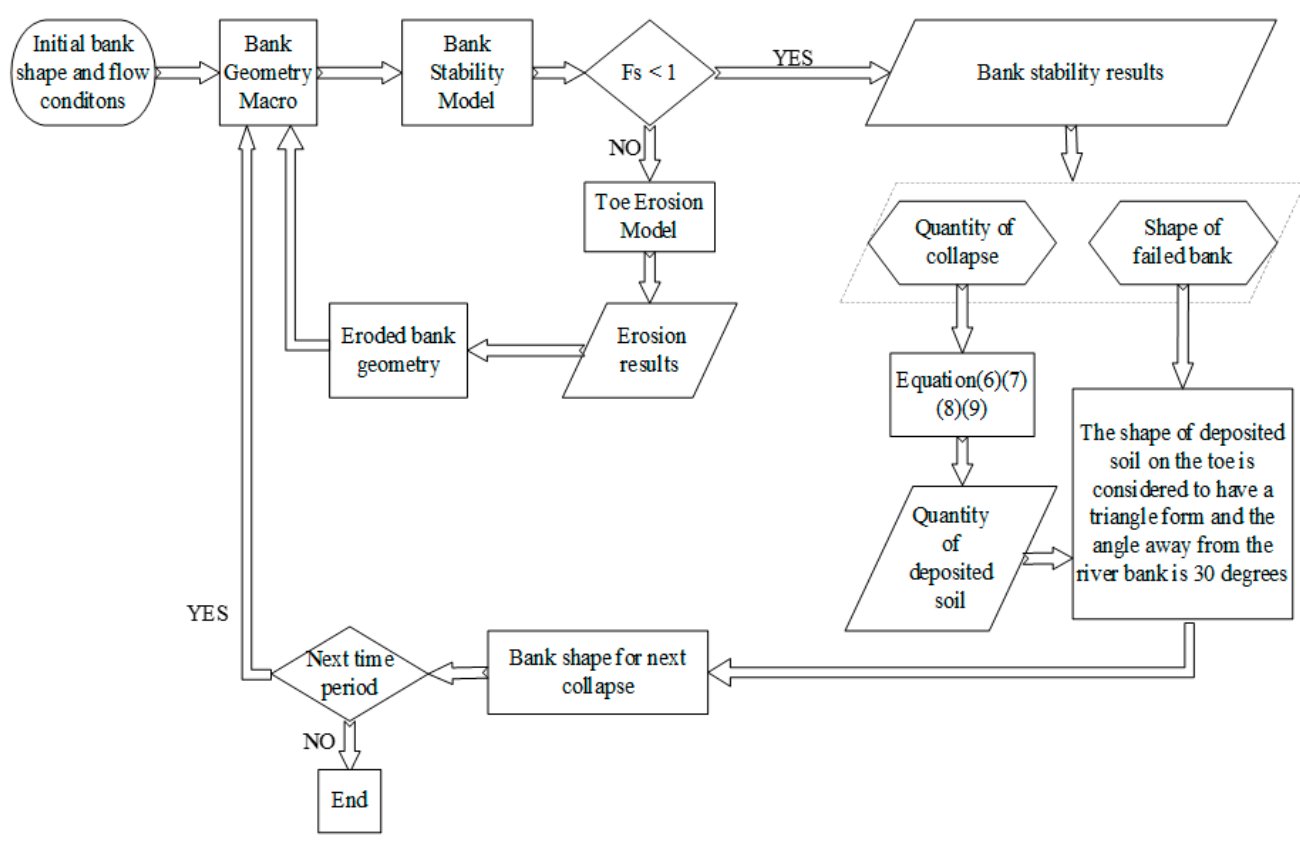

Figure 5. Flow chart of the established model.

Table 5. Numerical results, field measurements and errors for surveying Section 1 of Figure 1.

\begin{tabular}{cccc}
\hline Time Scale & $\begin{array}{c}\text { Calculating Collapse } \\
\text { Distance }(\mathbf{m})\end{array}$ & $\begin{array}{c}\text { Monitoring Collapse } \\
\text { Distance }(\mathbf{m})\end{array}$ & Error (\%) \\
\hline 21 May-13 July & 4.96 & 4.60 & 7.83 \\
14 July-9 August & 3.24 & 3.05 & 6.23 \\
10 August-23 September & 5.55 & 5.25 & 5.71 \\
23 September-30 September & 1.50 & 1.68 & 10.71 \\
Total collapse & 15.25 & 14.58 & 4.60 \\
\hline
\end{tabular}

Table 6. Numerical results, field measurements and errors for surveying Section 2 of Figure 1.

\begin{tabular}{cccc}
\hline Time Scale & $\begin{array}{c}\text { Calculating Collapse } \\
\text { Distance (m) }\end{array}$ & $\begin{array}{c}\text { Monitoring Collapse } \\
\text { Distance (m) }\end{array}$ & Error (\%) \\
\hline 21 May-13 July & 4.99 & 4.50 & 10.89 \\
14 July-9 August & 3.01 & 2.80 & 7.5 \\
10 August-23 September & 5.38 & 5.08 & 5.91 \\
23 September-30 September & 1.13 & 1.45 & 22.06 \\
Total collapse & 14.51 & 13.81 & 5.07 \\
\hline
\end{tabular}

Table 7. Numerical results, field measurements and errors for surveying Section 3 of Figure 1.

\begin{tabular}{cccc}
\hline Time Scale & $\begin{array}{c}\text { Calculating Collapse } \\
\text { Distance }(\mathbf{m})\end{array}$ & $\begin{array}{c}\text { Monitoring Collapse } \\
\text { Distance }(\mathbf{m})\end{array}$ & Error (\%) \\
\hline 21 May-13 July & 5.46 & 5.80 & 5.9 \\
14 July-9 August & 3.30 & 3.10 & 6.5 \\
10 August-23 September & 7.15 & 6.80 & 5.1 \\
23 September-30 September & 0.94 & 1.10 & 14.5 \\
Total collapse & 16.85 & 16.80 & 0.3 \\
\hline
\end{tabular}


Table 8. Numerical results, field measurements and errors for surveying Section 4 of Figure 1.

\begin{tabular}{cccc}
\hline Time Scale & $\begin{array}{c}\text { Calculating Collapse } \\
\text { Distance }(\mathbf{m})\end{array}$ & $\begin{array}{c}\text { Monitoring Collapse } \\
\text { Distance }(\mathbf{m})\end{array}$ & Error (\%) \\
\hline 21 May-13 July & 5.75 & 5.3 & 8.5 \\
14 July-9 August & 3.72 & 3.95 & 5.8 \\
10 August-23 September & 6.41 & 6.2 & 3.4 \\
23 September-30 September & 2.73 & 2.4 & 13.8 \\
Total collapse & 18.61 & 17.85 & 4.3 \\
\hline
\end{tabular}

Table 9. Numerical results, field measurements and errors for surveying Section 5 of Figure 1.

\begin{tabular}{cccc}
\hline Time Scale & $\begin{array}{c}\text { Calculating Collapse } \\
\text { Distance }(\mathbf{m})\end{array}$ & $\begin{array}{c}\text { Monitoring Collapse } \\
\text { Distance }(\mathbf{m})\end{array}$ & Error (\%) \\
\hline 21 May-13 July & 5.93 & 5.6 & 5.9 \\
14 July-9 August & 3.82 & 3.6 & 6.1 \\
10 August-23 September & 6.24 & 6.5 & 4 \\
23 September-30 September & 1.75 & 1.45 & 20.7 \\
Total collapse & 17.74 & 17.15 & 3.4 \\
\hline
\end{tabular}

By analyzing the results displayed in Tables 5-9, it is possible to confirm that the error between numerical and experimental values is between $6 \%$ and $20 \%$. There are multiple influencing factors that can affect this comparison and the shape of the bank toe, always changing under the action of water flow which provides the higher impact. As water and sand conditions are continuously varying, the error is considerably higher considering measurements vs numerical results for the smallest time frame monitored (23 September-30 September). On the other hand, for longer time scales, the total error is about $5 \%$. Overall, the numerical results are fairly consistent with the data recorded during the monitoring campaign, considering the significant modifications applied within the numerical model.

\section{Results and Discussion}

This section provides the further results obtained and their interpretation.

\subsection{Collapse Processes Obtained through Numerical Simulations with the Modified BSTEM Model}

The riverbank collapses simulated with the modified BSTEM model for the period 21 May-30 September in 2011 are illustrated in Figures 6-10 for surveying river Sections 1-5 respectively. Collapse rates of study sections in different months are listed in Table 10.

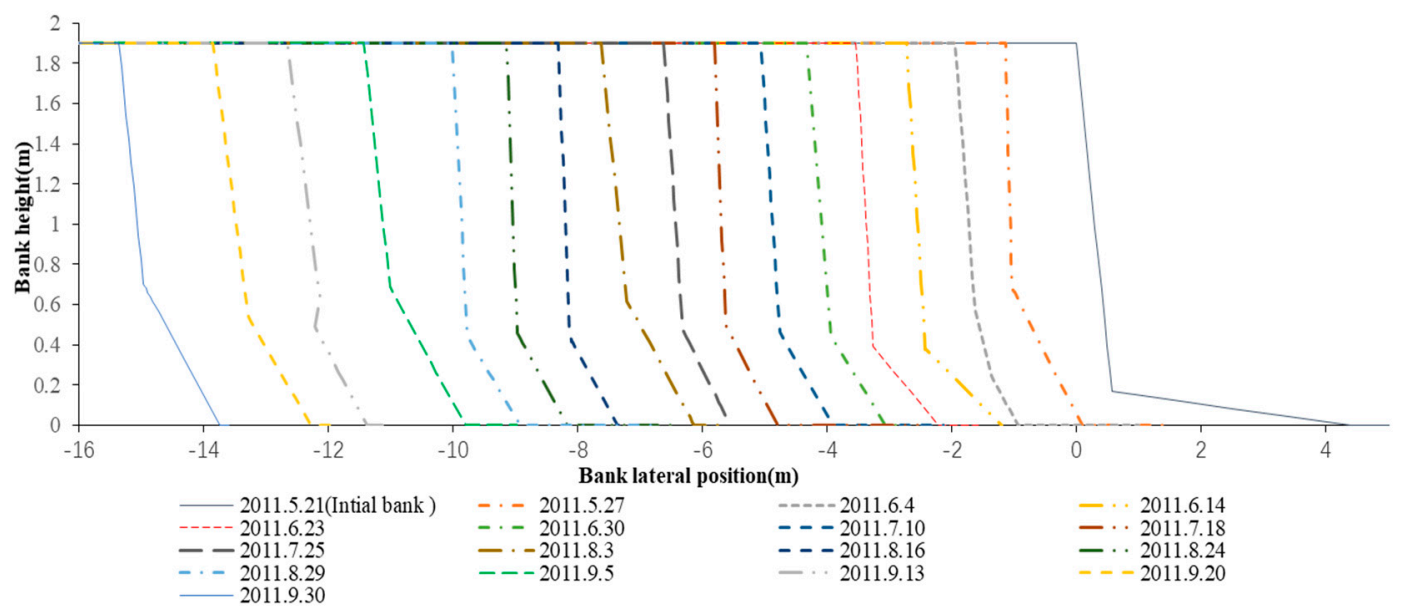

Figure 6. Collapse phases for surveying Section 1. 


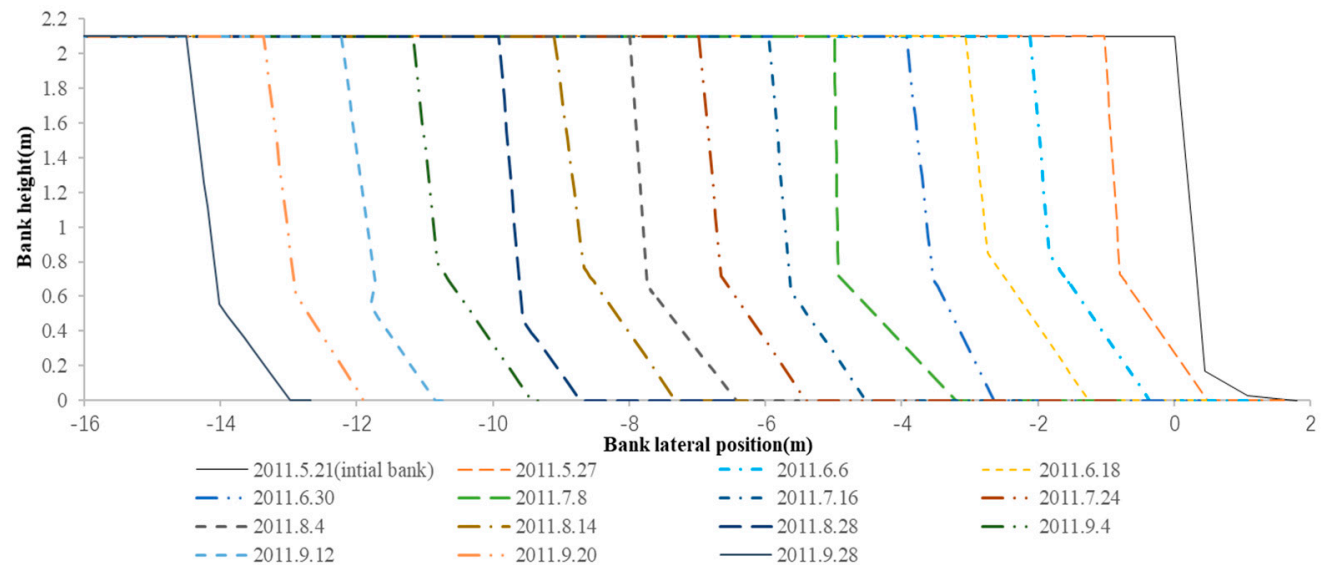

Figure 7. Collapse phases for Section 2.

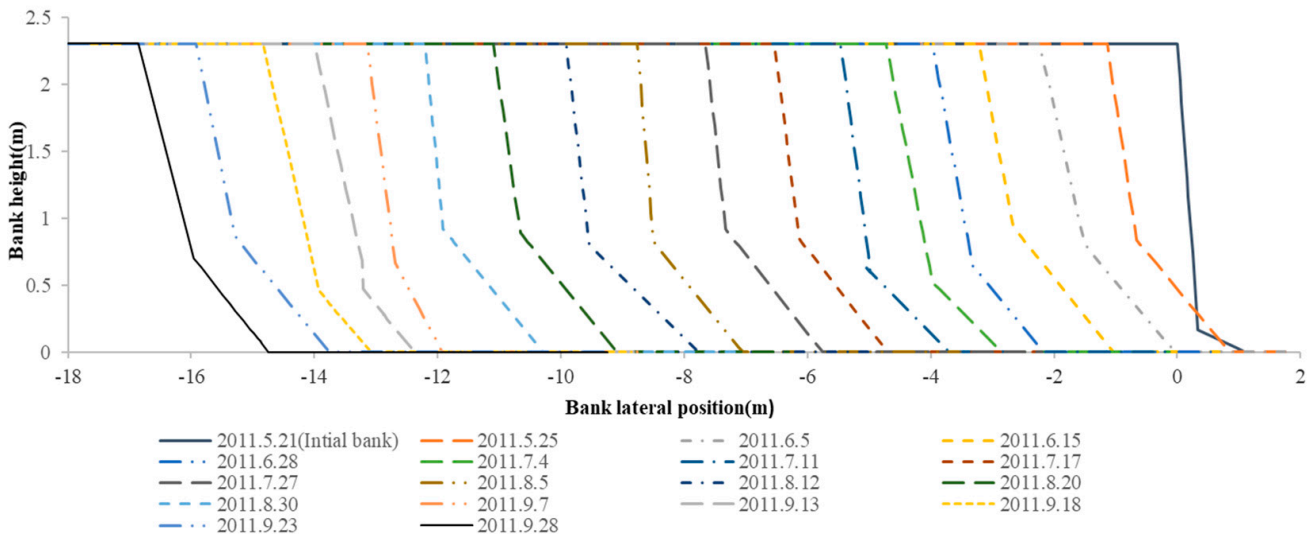

Figure 8. Collapse phases for Section 3.
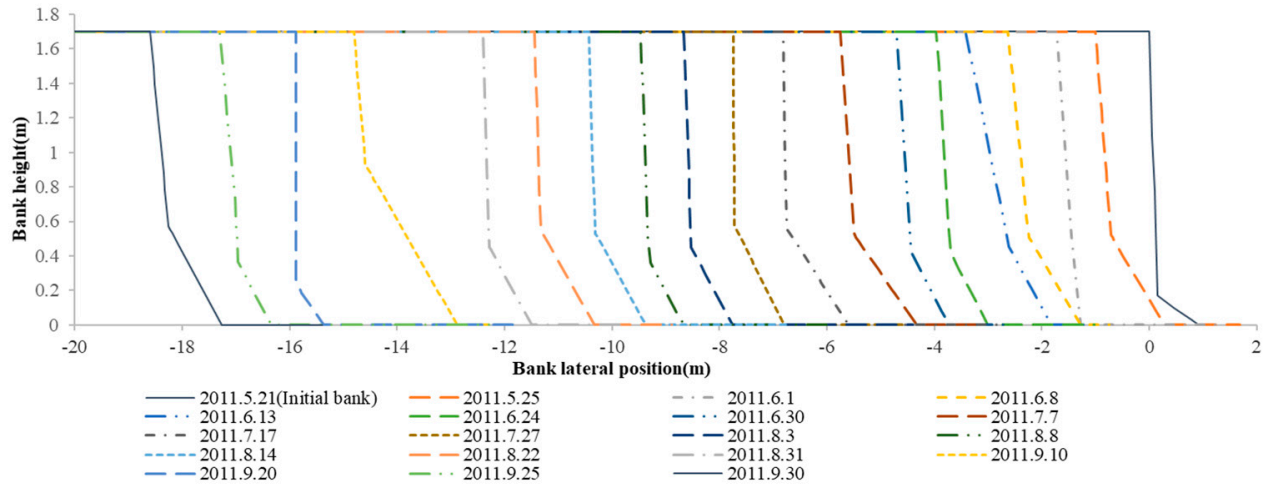

Figure 9. Collapse phases for Section 4.

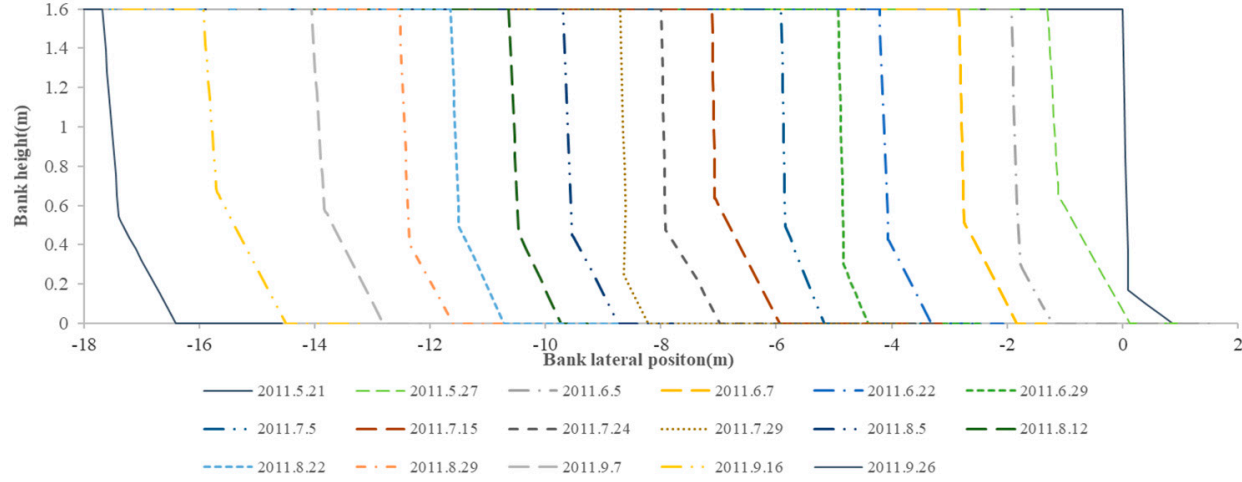

Figure 10. Collapse phases for Section 5. 
Table 10. Collapse rates of study sections in different months (Unit: $\mathrm{m} / \mathrm{d}$ ).

\begin{tabular}{cccccc}
\hline Month & Section 1 & Section 2 & Section 3 & Section 4 & Section 5 \\
\hline 5 & 0.095 & 0.094 & 0.104 & 0.091 & 0.118 \\
6 & 0.106 & 0.097 & 0.094 & 0.123 & 0.122 \\
7 & 0.074 & 0.098 & 0.119 & 0.098 & 0.123 \\
8 & 0.109 & 0.095 & 0.147 & 0.150 & 0.124 \\
9 & 0.178 & 0.153 & 0.155 & 0.207 & 0.172 \\
\hline
\end{tabular}

To identify hypothetical relationships between hydraulic conditions and collapse rates, different indicators recorded were plotted versus the collapse rates estimated, and factors obtained are displayed in Figure 11.

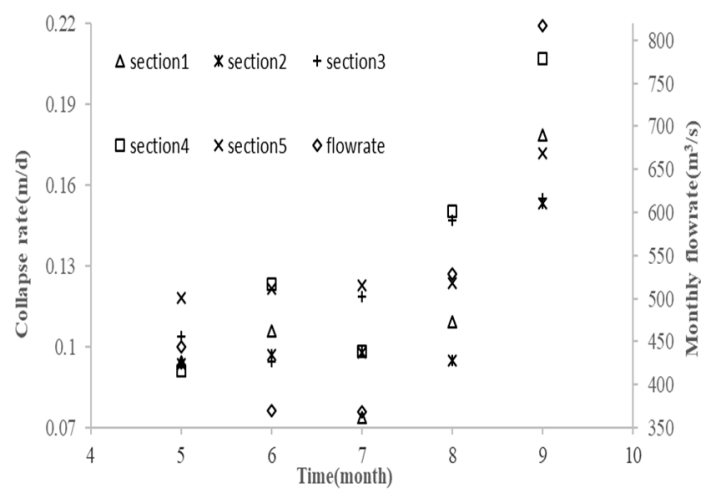

(a)

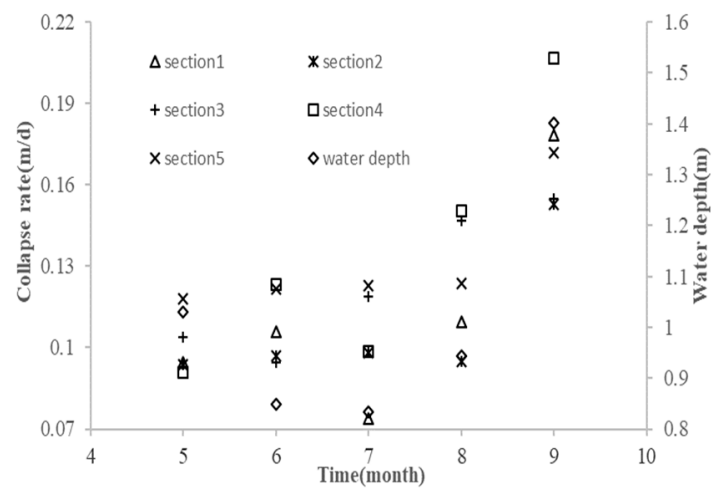

(b)

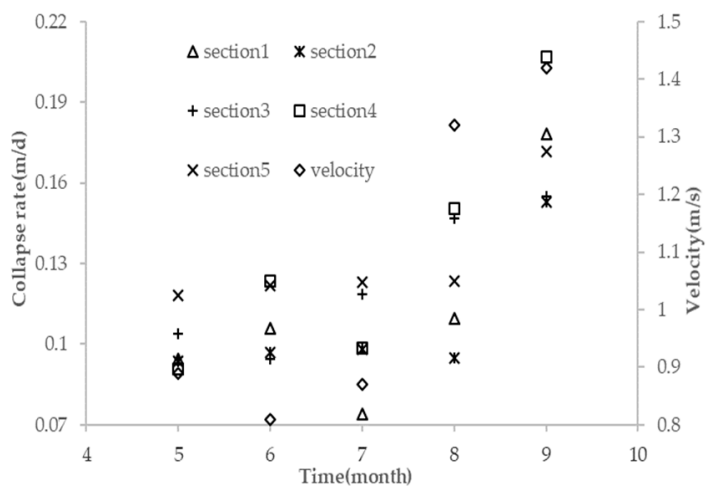

(c)

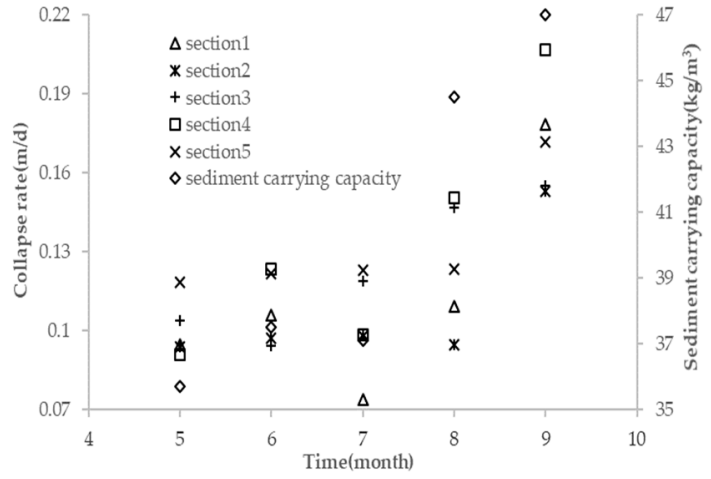

(d)

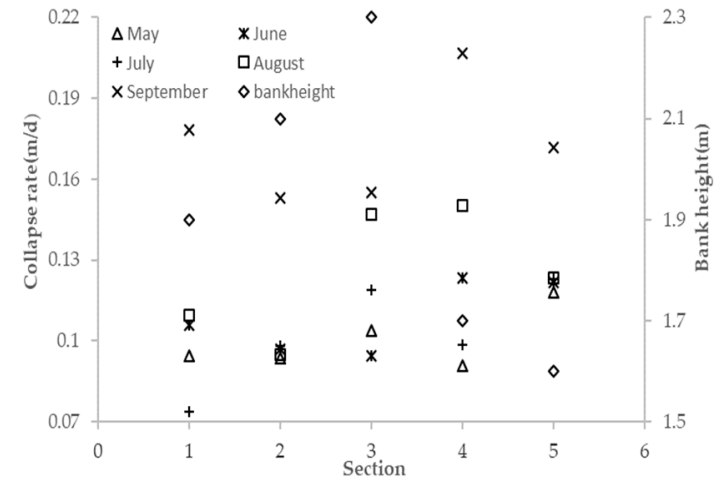

(e)

Figure 11. The relationship between flow conditions and collapse rates, the effects of (a) flowrate; (b) water depth; (c) velocity; (d) sediment carrying capacity; and (e) bank height. 
Because the flowrate, water depth, velocity and sediment carrying capacity were of similar magnitudes from June to July, the average collapse rate was used to discuss the effects on collapse rates by influencing factors previously highlighted, and their impacts can be observed in Figure 11.

The authors have attempted to characterize the continuous collapses influenced by multiple factors that can be divided into two categories: autologous and external. The autologous factor considered is the bank height, while external factors include flow rate, water depth, velocity and sediment carrying capacity. Different factors play dissimilar roles on influencing continuous collapse processes. For example, when flow rate, velocity and sediment carrying capacity rise, bank toe erosion can consequently increase due to higher shear stresses. Additionally, when water depth increases, soil shear strength diminishes due to the soil saturation, however the rise of water depth could also improve the bank stability due to the water pressure acting on the bank.

Even if bank collapses are continuously affected by these factors, there are still some interesting regular features observed in this study. For example, in Figure 11a-d, it can be observed that the collapse rate is positively correlated with the flow rate, water depth, velocity and capacity of carrying materials. Although the bank heights are all different in altered sections, collapse rates for the locations considered are higher in the flood season (July to September) than in the dry season (May to June), due to the increase of flow rates, water depth and velocities. Due to the strength of higher flow rates, the flow shear stress is typically greater than the soil shear stress, causing continuous erosion of the bank toe. It should also be noticed then that flow conditions are playing a leading role in the collapse processes and are the main dynamic factors for the quantity of material deposited.

Another interesting phenomenon which can be noticed within the results is that continuous collapse rates are bigger in May than in June, except for Section 3 (Figure 11). During this period, which belongs to the dry season, flow rates, water depth, velocities and sediment carrying capacities are all smaller (Table 3). This is due to the associated phenomena when water depths reduce, with a consequent loss in river bank stability and more intense bank collapses. However, for Section 3, the collapse distance decreases, and the authors believe that this is due to the bank height $(2.3 \mathrm{~m}$, the highest among the sections).

\subsection{Non Applicability of the Traditional BSTEM Method}

In order to further demonstrate that the original BSTEM model is not applicable for the representation of continuous long term bank collapses, numerical and experimental results are listed in Tables 11-15, together with the errors obtained.

Table 11. BSTEM results, field measurements and errors for surveying Section 1.

\begin{tabular}{cccc}
\hline Time Scale & $\begin{array}{c}\text { BSTEM Method } \\
\text { Results }(\mathbf{m})\end{array}$ & $\begin{array}{c}\text { Monitoring Collapse } \\
\text { Distance (m) }\end{array}$ & Error (\%) \\
\hline 21 May-13 July & 7.80 & 4.60 & 69.6 \\
14 July-9 August & 7.18 & 3.05 & 135.4 \\
10 August-23 September & 9.98 & 5.25 & 89.3 \\
23 September-30 September & 2.08 & 1.68 & 23.8 \\
Total collapse & 27 & 14.58 & 85.2 \\
\hline
\end{tabular}

Table 12. BSTEM results, field measurements and errors for surveying Section 2.

\begin{tabular}{cccc}
\hline Time Scale & $\begin{array}{c}\text { BSTEM Method } \\
\text { Results }(\mathbf{m})\end{array}$ & $\begin{array}{c}\text { Monitoring Collapse } \\
\text { Distance(m) }\end{array}$ & Error (\%) \\
\hline 21 May-13 July & 7.70 & 4.50 & 71.1 \\
14 July-9 August & 5.94 & 2.80 & 112.1 \\
10 August-23 September & 8.48 & 5.08 & 67.2 \\
23 September-30 September & 1.73 & 1.45 & 19.1 \\
Total collapse & 23.84 & 13.81 & 72.6 \\
\hline
\end{tabular}


Table 13. BSTEM results, field measurements and errors for surveying Section 3.

\begin{tabular}{cccc}
\hline Time Scale & $\begin{array}{c}\text { BSTEM Method } \\
\text { Results }(\mathbf{m})\end{array}$ & $\begin{array}{c}\text { Monitoring Collapse } \\
\text { Distance (m) }\end{array}$ & Error (\%) \\
\hline 21 May-13 July & 9.63 & 5.80 & 66.1 \\
14 July-9 August & 6.85 & 3.10 & 121.1 \\
10 August-23 September & 11.83 & 6.80 & 73.9 \\
23 September-30 September & 1.36 & 1.10 & 24.1 \\
Total collapse & 29.68 & 16.80 & 76.6 \\
\hline
\end{tabular}

Table 14. BSTEM results, field measurements and errors for surveying Section 4.

\begin{tabular}{cccc}
\hline Time Scale & $\begin{array}{c}\text { BSTEM Method } \\
\text { Results(m) }\end{array}$ & $\begin{array}{c}\text { Monitoring Collapse } \\
\text { Distance (m) }\end{array}$ & Error (\%) \\
\hline 21 May-13 July & 8.9 & 5.3 & 68.1 \\
14 July-9 August & 9.13 & 3.95 & 131.1 \\
10 August-23 September & 11.35 & 6.2 & 83.2 \\
23 September-30 September & 2.9 & 2.4 & 21 \\
Total collapse & 32.28 & 17.85 & 80.8 \\
\hline
\end{tabular}

Table 15. BSTEM results, field measurements and errors for surveying Section 5.

\begin{tabular}{cccc}
\hline Time Scale & $\begin{array}{c}\text { BSTEM Method } \\
\text { Results }(\mathbf{m})\end{array}$ & $\begin{array}{c}\text { Monitoring Collapse } \\
\text { Distance (m) }\end{array}$ & Error (\%) \\
\hline 21 May-13 July & 9.63 & 5.6 & 71.9 \\
14 July-9 August & 7.85 & 3.6 & 118.1 \\
10 August-23 September & 12.02 & 6.5 & 85 \\
23 September-30 September & 1.77 & 1.45 & 22 \\
Total collapse & 31.27 & 17.15 & 82.4 \\
\hline
\end{tabular}

It can be concluded that the errors are all very large for longer monitoring periods. That is due to the hypothesis implemented within the BSTEM method, commonly used to calculate collapse distance, considering no soil deposition at the bank toe after the collapse-an unrealistic condition.

\subsection{Discussions}

Comparing simulation results using the modified BSTEM model with field data collected, as showed in Tables 5-9, it can be observed that errors range from $0.3 \%$ to $5.07 \%$, hence are all acceptable and it is possible to confirm the reliability and accuracy of the modified BSTEM model to calculate continuous riverbank collapse.

Furthermore, additional outcomes have to be highlighted to increase the performance of the numerical model. Firstly, as the initial boundary conditions can have an impact on river bank collapse, supplementary studies have to be conducted to investigate this phenomenon. Secondly, due to the lack of advanced experimental measurement techniques, it is very difficult to get the river bed profile at every time step, and for this study a simplified bank shape was used in the calculations presented. This may be one more reason for the errors calculated. To solve this problem, sonar and electromagnetic wave measurement technologies may be adopted in future studies. Thirdly, in natural rivers, flow conditions such as flow rate and water depth vary continuously. To obtain bank collapse distances, monthly average flow conditions were used in this study, hence more targeted and accurate flow conditions should be used in future studies to improve the results. Finally, riverbed erosion and bank erosion typically occur at the same time and both are influenced by each other. For example, riverbed erosion influences the bank collapse by increasing the bank height and when the bank collapse happens, falling soil directly settles along the area where riverbed erosion happened before depositing at the bank toe. 
As all these aspects are crucial, by implementing them within the numerical model it is predicted that results will be more accurate.

\section{Conclusions}

(1) As confirmed by the observations made during the monitoring of the area, a single bank collapse can be divided into four different stages that can be summarized as: (i) bank toe erosion initiation; (ii) tension crack development; (iii) shearing initiation; and (iv) bank failure occurrence. When a single collapse happens, part of the collapsed soil is washed away by the water and the remaining part accumulates at the bank toe. The new shape of the bank formed after this process along the river becomes the initial form of the next bank collapse. Bank collapse processes in a longer time scale are continuous collapses that are made from single bank collapse during short time scales.

(2) Based on the original BSTEM model, a new modified version was implemented, applying several new assumptions. The original BSTEM assumed that the falling part which had collapsed from the riverbank did not accumulate on the toe and was immediately removed. This does not accurately represent the reality of the entire erosion process typical in natural rivers, and comparisons between experimental and numerical results have shown that, by using the original approach, significant errors will affect the numerical results, as listed in Tables 11-15.

Furthermore, to address this gap, a modified BSTEM was developed to obtain the quantity of collapsed sediment accumulating on the toe. Several parameters were introduced, such as sediment concentration, sediment carrying capacity and sediment setting velocity. The quantity of collapsed sediment accumulated on the toe could have been obtained using Formulas (6)-(9).

Additionally, another main goal modifying the BSTEM model was to obtain the new shape generated by the deposition of material on the bank toe. It should be noted that the boundary conditions play an important role in the calculations of continuous collapse processes for natural rivers. The new shape generated by the deposition of material on the bank toe was the initial boundary condition of next collapse process. Based on this, after observing multiple shapes during the erosion process following the collapse of material, the shape generated by the deposition of material on the bank toe was assumed to be triangular and the angle away from the riverbank was the angle of repose of sediment. After a single collapse, the new shape of the riverbank could have been obtained from the shape of the deposited sediment and the collapsed plain.

(3) Adopting all the previous modifications within the calculation of every single collapse process, the numerical results obtained using the modified BSTEM are consistent with the monitored datasets for continuous processes, as listed in Tables 5-9.

(4) The relationship between collapse rates and influencing factors was discussed and influencing factors were divided into two categories: autologous and external (flow conditions). Different factors play different roles in continuous collapse processes. For example, the flow rate, velocity and sediment carrying capacity rise can increase bank toe erosion by increasing flow shear stress. Water depth rise can reduce soil shear strength by promoting soil saturation, and water depth rise can also increase river bank stability by providing water pressure. Soil characteristics determine the shear strength of each material, and bank height plays an important role in the bank stability analysis. For similar flow conditions, a higher bank with a steeper slope is more unstable. These factors should be considered together to better characterize the collapse mechanisms.

(5) Aspects such as precisely determining the bank shape and quantifying the more singular flow conditions are crucial, and by implementing them within the numerical model it is predicted that results will become more accurate.

Author Contributions: All the authors jointly contributed to this research. A.S. was responsible for the proposition and design of the field monitoring and the modified BSTEM method; M.R. and G.D. analysed the experimental datasets and wrote the paper; and S.W. and F.Z. participated in the experiments.

Funding: The research reported in this manuscript is funded by the National Basic Research Program of China (Grant No. 2011CB403304) and National Natural Science Foundation of China (Grant No. 11372048). 
Acknowledgments: The research reported in this manuscript is supported by the National Basic Research Program of China (Grant No. 2011CB403304) and National Natural Science Foundation of China (Grant No. 11372048).

Conflicts of Interest: The authors declare no conflict of interest.

\section{References}

1. Nanson, G.C.; Hickin, E.J. A statistical analysis of bank erosion and channel migration in western Canada. Geol. Soc. Am. Bull. 1986, 97, 497-504. [CrossRef]

2. Shu, A.P.; Li, F.H.; Liu, H.F.; Duan, G.S.; Zhou, X. Characteristics of particle size distributions for the collapsed riverbank along the desert reach of the upper Yellow River. Int. J. Sediment. Res. 2016, 31, 291-298. [CrossRef]

3. Yao, Z.Y.; Ta, W.Q.; Jia, X.P.; Xiao, J.H. Bank erosion and accretion along the Ningxia-Inner Mongolia reaches of the Yellow River from 1958 to 2008. Geomorphology 2011, 127, 99-106. [CrossRef]

4. Hou, S. Analysis on recent channel evolution characteristics on Inner-Mongolia reaches of the Yellow River. Yellow River 1996, 18, 43-44.

5. Hou, S.; Chang, W.; Wang, P. Characteristics and cause of formation of channel atrophy at Inner Mongolia section of the Yellow River. Yellow River 2007, 29, 25-29.

6. Wu, J.M.; Wang, R.S.; Yao, J.H. Remote sensing monitoring and study on the change of the Yellow River course in Yinchuan plain sector. Remote Land Resour. 2006, 18, 36-40.

7. Ta, W.Q.; Xiao, H.L.; Dong, Z.B. Long-term morphodynamic changes of a desert reach of the Yellow River following upstream large reservoirs' operation. Geomorphology 2008, 7, 249-259. [CrossRef]

8. Grabowski, R.C.; Droppo, I.G.; Wharton, G. Erodibility of cohesive sediment: The importance of sediment properties. Earth-Sci. Rev. 2011, 105, 101-120. [CrossRef]

9. Thorne, C.R. Processes and mechanisms of river bank erosion. In Gravel-Bed Rivers; Bathurst, J.C., Thorne, C.R., Eds.; Wiley and Sons: Chichester, UK, 1982; pp. 227-259.

10. ASCE Task Committee on Hydraulics; Bank Mechanics; Modeling of River Width Adjustment. River width adjustment. I: Processes and mechanisms. J. Hydraul. Eng. 1998, 124, 881-902. [CrossRef]

11. Shields, A.; Ott, W.P.; Uchelen, J.C.V. Application of Similarity Principles and Turbulence Research to Bed-Load Movement; Soil Conservation Service Cooperative Laboratory California Institute of Technology: Pasadena, CA, USA, 1936.

12. Buffington, J.M.; Montgomery, D.R. A systematic analysis of eight decades of incipient motion studies, with special reference to gravel-bedded rivers. Water Resour. Res. 1997, 33, 1993-2029. [CrossRef]

13. Hooke, J.M. An analysis of the processes of riverbank erosion. J. Hydrol. 1979, 42, 39-62. [CrossRef]

14. Grissinger, E.H. Bank erosion of cohesive materials. In Gravel-Bed Rivers; Thorne, C.R., Bathurst, J.C., Eds.; Wiley and Sons: Chichester, UK, 1982; pp. 273-287.

15. Simon, A.; Collison, A.J.C. Pore-water pressure effects on the detachment of cohesive streambeds: Seepage forces and matric suction. Earth Surf. Process. Landf. 2001, 26, 1421-1442. [CrossRef]

16. Julian, J.P.; Torres, R. Hydraulic erosion of cohesive riverbanks. Geomorphology 2006, 76, 193-206. [CrossRef]

17. Twidale, C.R. Erosion of an alluvial bank at Birdwood, South Australia. Z. Geomorphol. 1964, 8, $189-211$.

18. Lawler, D.M. The measurement of river bank erosion and lateral channel change: A review. Earth Surf. Process. Landf. 1993, 18, 777-821. [CrossRef]

19. Rinaldi, M.; Casagli, N. Stability of streambanks formed in partially saturated soils and effects of negative pore water pressures: The Sieve River (Italy). Geomorphology 1999, 26, 253-277. [CrossRef]

20. Singer, M.J.; Munns, D.N. Soils: An Introduction; Prentice Hall Inc.: Upper Saddle River, NJ, USA, 1999; pp. 14-46. ISBN 9780131190191.

21. Couper, P. Effects of silt-clay content on the susceptibility of riverbanks to subaerial erosion. Geomorphology 2003, 56, 95-108. [CrossRef]

22. Musa, J.J.; Abdulwaheed, S.; Saidu, M. Effect of surface runoff on Nigerian rural roads (a case study of Offa local government area). AU J. Technol. 2010, 13, 242-248.

23. Wolman, M.G. Factors influencing erosion of a cohesive river bank. Am. J. Sci. 1959, 257, 204-216. [CrossRef]

24. Knighton, A.D. Riverbank erosion in relation to streamflow conditions, River Bollin-Dean, Cheshire. East Midl. Geogr. 1973, 5, 416-426.

25. Albidin, R.Z.; Sulaiman, M.S.; Yusoff, N. Erosion risk assessment: A case study of the Langat Riverbank in Malaysia. Int. Soil Water Conserv. Res. 2017, 5, 26-35. [CrossRef] 
26. Yu, M.; Wei, H.; Wu, S. Experimental study on the bank erosion and interaction with near-bank bed evolution due to fluvial hydraulic force. Int. J. Sediment. Res. 2015, 1, 81-89. [CrossRef]

27. Yang, G.S.; Tuo, W.Q.; Dai, F.N.; Liu, Y.X.; Jing, K.; Li, B.Y.; Zhang, O.Y.; Lu, R.; Hu, L.F.; Tao, Y. Contribution of sand sources to the silting of riverbed in Inner Mongolia section of Huanghe River. J. Desert Res. 2003, 23, 152-159.

28. Feng, G. The coarse sediment of the Yellow River mainly from wind sand. J. Soil Water Conserv. 1992, 3 , $45-47$.

29. Jing, K.; Li, J.; Li, F. Erosion yield from the middle Yellow River basin and tendency prediction. Acta Geogr. Sin. 1998, 53, 107-115.

30. Jing, K.; Li, J.; Li, F. Study on delimitation of coarse sand area in the middle Yellow River. J. Soil Water Conserv. 1997, 3, 10-15.

31. Xu, J.H.; Lv, G.C.; Zhang, S.L.; Gan, Z.M. Definition of the Source Area of Centralized Coarse Sediment and Sediment Yield and Transportation in the Middle Yellow River; Yellow River Press: Zhengzhou, China, 2000; pp. 11-36, ISBN 9787806214527.

32. Bai, T.; Ma, R.; Ma, X.; Ha, Y.; Huang, Q. Threshold of water and sediment in desert wide valley reaches upper the Yellow River. J. Desert Res. 2018, 38, 645-650.

33. Yu, M.; Shen, K.; Zhang, J.H. Preliminary investigation on bank properties and sediment source in Yellow River Ningmeng River Reach. Int. J. Sediment. Res 2014, 4, 39-42.

34. Rijn, L.C.V. Principles of Sediment Transport in Rivers, Estuaries and Coastal Seas; Aqua Publications: Delft, The Netherlands, 1993; ISBN 90-800356-2-9.

35. Catano, Y.; Passoni, G.; Pacheco, R.G.; Toro, F.M.; Naranjo, B.J. Comparison between different numerical solutions for the hydraulic dam-break wave. In Proceedings of the Iche 98-International Conference on Hydro-sciences and Engineering, Berlin, Germany, 31 August-3 September 1998.

36. Toro, E.F. Shock-Capturing Methods for Free-Surface Shallow Flows; Wiley: New York, NY, USA, 2001; pp. 566-571, ISBN 9780471987666.

37. Cao, Z.; Day, R.; Egashira, S. Coupled and decoupled numerical modeling of flow and morphological evolution in alluvial rivers. J. Hydraul. Eng. 2002, 128, 306-321. [CrossRef]

38. Hudson, J.; Sweby, P.K. A high-resolution scheme for the equations governing 2D bed-load sediment transport. Int. J. Numer. Meth. 2005, 47, 1085-1091. [CrossRef]

39. Simon, A.; Curini, A.; Darby, S.E.; Langendoen, E.J. Bank and near-bank processes in an incised channel. Geomorphology 2000, 35, 193-217. [CrossRef]

40. Zong, Q.; Xia, J.; Deng, C.; Xu, Q.X. Modeling of the composite bank failure process using BSTEM. J. Sichuan Univ. 2013, 45, 69-78.

41. Simon, A.; Pollen-Bankhead, N.; Mahacek, V.; Langendoen, E. Quantifying reductions of mass-failure frequency and sediment loadings from streambanks using toe protection and other means: Lake Tahoe, United States. J. Am. Water Resour. Assoc. 2009, 45, 170-186. [CrossRef]

42. Lindow, N.; Fox, G.A.; Evans, R.O. Seepage erosion in layered stream bank material. Earth Surf. Process. Landf. 2009, 34, 1693-1701. [CrossRef]

43. Wilson, G.V.; Perketi, R.K.; Fox, G.A.; Dabney, S.M.; Shields, F.D.; Cullum, R.F. Soil properties controlling seepage erosion contributions to streambank failure. Earth Surf. Process. Landf. 2007, 32, 447-459. [CrossRef]

44. Cancienne, R.M.; Fox, G.A.; Simon, A. Influence of seepage undercutting on the stability of root-reinforced streambanks. Earth Surf. Process. Landf. 2008, 33, 1769-1786. [CrossRef]

45. Xiao, C.; Hao, Y.; Liu, F. Analysis of climate change for Dengkou in recent 52 years. J. Arid Land Resour. Environ. 2008, 22, 90-93.

46. Kolerski, T.; Shen, H.T. Possible effects of the 1984 St Clair River Ice jam on bed changes. Can. J. Civ. Eng. 2015, 42, 696-703. [CrossRef]

47. Kolerski, T.; Shen, H.T. St. Clair River ice jam dynamics and possible effect on bed changes. In Proceedings of the 20th IAHR International Symposium on Ice, Lahti, Finland, 14-18 June 2010.

48. Thorne, C.R.; Tovey, N.K. Stability of composite riverbanks. Earth Surf. Process. Landf. 1981, 6, $469-484$. [CrossRef]

49. Shu, A.P.; Gao, J.; Li, F.H. Lateral variation properties in river channels due to bank failure along the desert valley reach of upper Yellow River. Adv. Water Sci. 2014, 25, 77-82. 
50. Osman, A.M.; Thorne, C.R. Riverbank stability analysis. I: Theory. J. Hydraul. Eng. 1988, 114, $134-150$. [CrossRef]

51. Darby, S.E.; Thorne, C.R. Numerical simulation of widening and bed deformation of straight sand-bed rivers. I: Model development. J. Hydraul. Eng. 1996, 122, 184-193. [CrossRef]

52. Midgley, T.L.; Fox, G.A.; Heeren, D.M. Evaluation of the bank stability and toe erosion model (BSTEM) for predicting lateral retreat on composite streambanks. Geomorphology 2012, 145, 107-114. [CrossRef]

53. Garcia, M.H. Sedimentation Engineering; American Society of Civil Engineers: Reston, VA, USA, 2008; pp. 21-163, ISBN 9780784408148.

54. Rinaldi, M.; Mengoni, B.; Luppi, L.; Darby, S.E.; Mosselman, E. Numerical simulation of hydrodynamics and bank erosion in a river bend. Water Resour. Res. 2008, 44, 303-312. [CrossRef]

55. Hanson, G.J. Surface erodibility of earthen channels at high stresses. Part II-Developing an in-situ testing device. Trans. ASAE 1990, 33, 127-131. [CrossRef]

56. Amiritokaldany, E.; Darby, S.E.; Tosswell, P. Bank stability for predicting reach-scale land loss and sediment yield. J. Am. Water Resour. Assoc. 2003, 39, 897-910. [CrossRef]

57. Langendoen, E.J.; Simon, A. Modeling the evolution of incised streams. II: Streambank erosion. J. Hydraul. Eng. 2008, 134, 905-915. [CrossRef]

58. Samadi, A.; Amiritokaldany, E.; Darby, S.E. Identifying the effects of parameter uncertainty on the reliability of riverbank stability modelling. Geomorphology 2009, 106, 219-230. [CrossRef]

59. Taghavi, M.; Dovoudi, M.H.; Amiritokaldany, E.; Darby, S.E. An analytical method to estimate failure plane angle and tension crack depth for use in riverbank stability analyses. Geomorphology 2010, 123, 74-83. [CrossRef]

60. Dodaro, G.; Tafarojnoruz, A.; Stefanucci, F.; Adduce, C.; Calomino, F.; Gaudio, R.; Sciortino, G. An experimental and numerical study on the spatial and temporal evolution of a scour hole downstream of a rigid bed. In Proceedings of the International Conference on Fluvial Hydraulics, Lausanne, Switzerland, 3-5 September 2014; pp. 1415-1422.

61. Dodaro, G.; Tafarojnoruz, A.; Sciortino, G.; Adduce, C.; Calomion, F.; Gaudio, R. Modified Einstein sediment transport method to simulate the local scour evolution downstream of a rigid bed. J. Hydraul. Eng. 2016, 142. [CrossRef]

62. Wang, X.K.; Shao, X.J.; Li, D.X. Fundamental River Mechanics; China Water and Power Press: Beijing, China, 2002; pp. 54-98, ISBN 7-5084-1093-9.

63. Gaudio, R.; Tafarojnoruz, A.; Calomino, F. Combined flow-altering countermeasures against bridge pier scour. J. Hydraul. Res. 2012, 50, 35-43. [CrossRef]

64. Tafarojnoruz, A.; Gaudio, R.; Calomino, F. Bridge pier scour mitigation under steady and unsteady flow conditions. Acta Geophys. 2012, 60, 1076-1097. [CrossRef]

65. Tang, C.B. Laws of sediment incipient motion. J. Hydraul. Eng. 1963, 2, 3-14. 